\title{
Keefektifan Tata Ruang Kantor pada Bagian Arsip di PT Bosowa Berlian Motor Makassar
}

\author{
Rahmawati $^{1}$, Aris Baharuddin ${ }^{2}$, Nasaruddin ${ }^{2}$, Haerul $^{1}$ \\ Pendidikan Administrasi Perkantoran, Universitas Negeri Makassar \\ Politeknik Informatika Nasional (Polinas), Makassar \\ Email: aris.baharuddin@gmail.com
}

\begin{abstract}
ABSTRAK
Penelitian ini bertujuan untuk mengetahui keefektifan tata ruang kantor pada bagian arsip di PT. BosowaBerlian Motor Makassar. Penelitian ini menggunakan jenis penelitian deskriptif kuantitatif dengan teknik pengumpulan data observasi, angket, wawancara dan dokumentasi. Populasi pada penelitian ini seluruh karyawan di PT. Bosowa Berlian Motor yang berjumlah sebanyak 136 orang dan sampel dalam penelitian ini sebanyak 50 persen yang totalnya adalah 68 responden. Adapun teknik analisis data yang digunakan yaitu dengan menggunakan analisis deskriptif yaitu mempersentasikan setiap item pertanyaan dengan menggunakan rumus persentase. Hasil penelitian menunjukkan bahwa ketiga indikator dalam penelitian ini pada umumnya menunjukkan hasil yang cukup efektif, mulai dari indikator perencangan tata ruang kantor yang hasilnya cukup efektif, indikator penempatan karyawan yang hasilnya cukup efektif, dan indikator lingkungan fisik kantor yang hasilnya efektif. Dari ketiga indikator tersebut memberikan gambaran yang dapat disimpulkan bahwa tata ruang kantor pada bagian arsip di PT. Bosowa Berlian Motor Makassar secara keseluruhan dinilai cukup efektif.
\end{abstract}

Kata Kunci: Keefektifan, Tata Ruang Kantor

\begin{abstract}
This study aims to determine the effectiveness of office layout in the archive section at PT. Bosowa Berlian Motor Makassar. This research uses quantitative descriptive research with observation, questionnaire, interview and documentation data collection techniques. The population in this study all employees at PT. Bosowa Berlian Motor, amounting to 136 people and the sample in this study as much as 50 percent, the total was 68 respondents. The data analysis technique used is by using descriptive analysis that is to present each question item using a percentage formula. The results showed that the three indicators in this study generally showed quite effective results, starting from the indicators of office spatial planning, the results of which were quite effective, indicators of employee placement whose results were quite effective, and indicators of the office's physical environment whose results were effective. Of the three indicators provide an overview that can be concluded that the office layout in the archive section at PT. Bosowa Berlian Motor Makassar as a whole is considered quite effective.
\end{abstract}

Keywords: Effectiveness, Office Spatial Planning 
34| Jurnal Office, Vol. 4, No. 1, Januari-Juni 2018

\section{PENDAHULUAN}

Setiap organisasi baik pemerintahan maupun swasta, pasti didalamnya terdapat kantor. Hal tersebut dikarenakan segala bentuk aktivitas dari organisasi dilaksanakan di kantor oleh pegawainya dalam rangka mencapai tujuan organisasi tersebut. Dalam organisasi dalam rangka menyelenggarakan kegiatan kerjasama untuk mencapai tujuan yang telah ditetapkan sebelumnya tidak terlepas dari unsur-unsur yang mendukungnya. Hal ini mengandung makna bahwa manusia senantiasa menginginkan berhubungan dengan orang lain, dalam hubungan dengan orang lain itulah menimbulkan interaksi yang akan membentuk suatu organisasi (Akib \& Salam, 2016; Jamaluddin, Salam, Yunus, \& Akib, 2017; Saggaf, Salam, Kahar, \& Akib, 2014; Tadampali, Hadi, \& Salam, 2016).

Tata ruang kantor merupakan salah satu faktor yang memiliki peranan utama dalam menentukan kelancaran suatu perkejaan lembaga atau organisasi, tata ruang kantor yang baik dalam proses pekerjaan dapat menempuh jarak yang pendek dan baik yaitu kurang lebih 4 meter dari satu meja kemeja lainnya jarak yang lebih pendek berarti suatu pekerjaan dapat diselesaikan dalam waktu yang lebih singkat dan sukses tidaknya suatu lembaga / organisasi tergantung kepada tata ruang kantor. Tata ruang kantor merupakan penentuan mengenai kebutuhan ruang dan penggunaan secara terperinci dari ruang ini untuk menciptakan susunan yang praktis dari faktor fisik yang dianggap perlu bagi pelaksanaan kerja perkantoran dengan biaya yang layak. Fungsi dari tata ruang kantor tidak hanya menempatkan perlengkapan dan peralatan pada suatu kantor, tetapi tata ruang kantor harus dapat digunakan untuk mengatur dan memudahkan pergerakan alur kerja pegawai dari satu ruang ke ruang lain. Suatu ruang kantor yang efektif dan efisien tidak tercipta dengan sendirinya, melainkan hasil dari perencanaan yang tepat. Efektifitas kerja adalah penyelesaian pekerjaan tepat pada waktu yang telah ditetapkan, artinya apakah pelaksanaan suatu tugas dinilai baik atau tidak sangat tergantung pada bagaimana tugas itu diselesaikan, dan tidak terutama menjawab pertanyaan bagaimana cara melaksanakannya dan berapa biaya yang perlu dikeluarkan untuk itu. Guna meningkatkan efektifitas kerja pegawai (Erawati, Darwis, \& Nasrullah, 2017; Husain, Amirullah, \& Saleh, 2015; Simatupang \& Akib, 2007, 2011).

Pada dasarnya tata ruang kantor berhubungan langsung dengan manajemen perkantoran. Kantor adalah tempat penyedia informasi dalam rangka memperlancar tugas maupun aktifitas kerja di segala bidang. Dengan demikian kantor merupakan tempat diselenggarakannya aktifitas-aktifitas yang berkaitan dengan informasi untuk memperlancar kegiatan pekerjaan kantor. Menata ruang kantor merupakan kebutuhan dari perkantoran modern saat ini. Peranan tata ruang kantor memberi nilai tambah bagi kelangsungan aktifitas perusahaan seperti yang dikemukakan oleh Sedarmayanti bahwa "Tata ruang merupakan pengaturan dan penyusunan seluruh mesin kantor, alat perlengkapan kantor serta perabot kantor pada tempat yang tepat, sehingga pegawai dapat bekerja dengan baik, nyaman, leluasa dan bebas untuk bergerak, sehingga tercapai efisiensi kerja". Demikian halnya dengan kantor PT. Bosowa Berlian Motor Makassar sebagai salah satu perusahaan besar yang di dalamnya memiliki termasuk berbagai ruangan yang ditempati oleh para karyawan dalam melaksanakan pekerjaannya.

Penataan tata ruang kantor sangatlah penting, sebab tata ruang yang baik akan membawa perasaan nyaman bagi orang yang di dalamnya dan juga dengan adanya perasanaan yang nyaman tentu adalah langkah awal untuk menciptakan produktivitas kerja karyawan. Tata ruang kantor yang baik dan efisien tidak tercipta dengan sendirinya, melainkan hasil dari perencanaan 
yang tepat dari seseorang atau tim yang bertanggungjawab dalam merancang ruang kantor dan mereka harus memahami dulu bahwa pemakaian ruang suatu kantor merupakan proses yang berjalan terus mengikuti beragam kebutuhan dan tuntutan pekerjaan.

\section{METODE PENELITIAN}

Pengukuran variabel dalam penelitian ini dilakukan dengan skala oridinal dengan standar sebagaimana yang dikemukakan Arikunto sebagai berikut :76 \% - $100 \%$ : dikategorikan baik, $56 \%-75 \%$ : dikategorikan cukup, $40 \%$ - $55 \%$ dikategorikan kurang, Kurang dari $40 \%$ : dikategorikan tidak baik. Selanjutnya, untuk keperluan analisis kuantitatif, maka jawaban dari responden diberik skor dengan menggunakan skala likert. Populasi dalam penelitian ini yaitu karyawan pada kantor PT Bosowa Berlian Motor Makassar jumlah populasi sebesar 136 orang karyawan. Dengan menggunakan penarikan sampel $50 \%$ dari populasi yang ada maka sampel dalam penelitian ini berjumlah 68 karyawan.

\section{HASIL PENELITIAN PEMBAHASAN}

\section{Perancangan tata ruang kantor}

Indikator perancangan tata ruang kantor pada keefektifan tata ruang kantor pada bagian arsip di PT. Bosowa Berlian Motor adalah berada pada kategori cukup baik dengan hasil yang diperoleh sebesar 61,25 persen yang nilai tersebut berada pada standar pengukuran variabel yaitu 56\%-75\% yang bararti cukup baik. Dengan hasil nilai persentase yang diperoleh pada indikator perancangan tata ruang kantor ini dapat dipahami bahwa di PT. Bosowa telah dilakukan perancangan dengan cukup baik mulai dari penataan perabot kantor, penataan dan pengaturan lemari arsip yang sehingga hal itu membuat kondisi para karyawan dalam berlalu lintas di dalam ruang arsip tidak menjadi hamabatan bagi para karyawan tersebut.

\section{Penempatan karyawan}

Indikator penempatan karyawan pada keekfektifan tata ruang kantor pada bagian arsip di PT. Bosowa Berlian Motor adalah berada pada kategori cukup baik dengan hasil persentase yang diperoleh sebesar 64,76 persen yang hasil tersebut berada pada standar kategori di dalam pengukuran variabel yaitu 56\%-75\%. Hasil persentasi diatas yang dikatakan cukup baik atau cukup efektif dikarenakan penempatan karyawan yang ditempatkan pada bagian arsip di PT. Bosowa Berlian Motor itu telah memberikan rasa kenyamana bagi karyawan tersebut untuk bekerja, dan selain itu jumlah karyawan yang ditempatkan di ruang arsip sudah sesuai dengan luas ruangan tersebut dan bebab pekerjaan yang ada di bagian arsip juga sudah sesuai dengan jumlah karyawan yang ditempatkan yaitu sebanyak 3 orang.

\section{Lingkungan fisik kantor}

Indikator linkungan fisik kantor pada tata ruang kantor di PT Bosowa Berlian Motor Makassar adalah berada pada kategori baik dengan hasil yang diperoleh 77,22 persen yang 


\section{6| Jurnal Office, Vol. 4, No. 1, Januari-Juni 2018}

berada pada standar kategori yaitu $76 \%-100 \%$. Hal ini jelas dapat dikatakan tata ruang kantor yang dilihat dari aspek lingkungan fisik kantor sudah efektif. Lingkungan fisik kantor pada bagian arsip yang telah dinilai efektif ini dikarenakan sistem pencahayaan yang ada di dalam ruangan itu sudah baik dimana para karyawan dalam melihat secara jelas segala prabotan kantor dengan jelas dan juga karyawan dapat melihat dengan jelas tulisan-tulisan pada lembaran dokumen. Selain itu, nampak juga kondisi di dalam ruang arsip yang memiliki ventilasi udara yang sehingga sirkulasi udara atau pertukaran udara luar dengan udara dalam ruangan dapat terjadi, dan setiap pemilihan warna baik itu warna dindin maupun warna pada perabot kantor seperti meja, lemari, kusen jendela itu semuanya juga memiliki warna yang kontraks dengan benda lainnya sehingga dengan adanya perpaduan warna yang baik itu membuat karyawan merasa lebih nyaman untuk melaksanakan tugas pekerjaannya.

\section{SIMPULAN}

Keefektifan tata ruang kantor pada bagian arsip di PT Bosowa Berlian Motor Makassar, maka dapat ditarik kesimpulan sebagai berikut; ketiga indikator yang menjadi pengukuran dalam penelitian ini pada umumnya menunjukkan hasil yang cukup efektif, mulai dari indikator perencangan tata ruang kantor yang hasilnya cukup efektif, indikator penempatan karyawan yang hasilnya cukup efektif, dan indikator lingkungan fisik kantor yang hasilnya efektif. Dari ketiga indikator tersebut memberikan gambaran yang dapat disimpulkan bahwa tata ruang kantor pada bagian arsip di PT. Bosowa Berlian Motor Makassar secara keseluruhan dinilai cukup efektif.

\section{DAFTAR PUSTAKA}

Akib, H., \& Salam, R. (2016). Analisis Kualitas Pelayanan Publik Berbasis Importance Performance Analysis (IPA) pada Kecamatan Kota Makassar. Jurnal Ilmiah Scientific Pinisi, 2(April 2016), 16-20.

Erawati, I., Darwis, M., \& Nasrullah, M. (2017). Efektivitas Kinerja Pegawai pada Kantor Kecamatan Pallangga Kabupaten Gowa. Jurnal Office, 3(1), 13-18.

Husain, L., Amirullah, A. H., \& Saleh, S. (2015). Efektivitas Pelaksanaan Pelayanan Kearsipan Pada Dinas Pendidikan Provinsi Sulawesi Selatan. Jurnal Ad'ministrare, 2(1), 46-52.

Jamaluddin, J., Salam, R., Yunus, H., \& Akib, H. (2017). Pengaruh Budaya Organisasi terhadap Kinerja Pegawai pada Dinas Pendidikan Provinsi Sulawesi Selatan. Jurnal Ad'ministrare, 4(1), 25-34.

Saggaf, S., Salam, R., Kahar, F., \& Akib, H. (2014). Pelayanan Fungsi Administrasi Perkantoran Modern. Jurnal Ad'ministrare, 1(1), 20-27.

Simatupang, P., \& Akib, H. (2007). Potret Efektivitas Organisasi Publik: Review Hasil Penelitian. Manajemen Usahawan Indonesia, 36(1), 35-41.

Simatupang, P., \& Akib, H. (2011). Efektivitas Implementasi dan Dampak Kebijakan dalam Konteks Desentralisasi Pemerintahan. Ilmu Administrasi Publik, 2(1), 1-9.

Tadampali, A. C. T., Hadi, A., \& Salam, R. (2016). Pengaruh Iklim Organisasi terhadap Turnover Intention Melalui Kepuasan Kerja sebagai Variabel Intervening pada PT Bank SulSelBar. Jurnal Ilmiah Ilmu Administrasi Publik, 6(2), 35-46. 